\title{
Nyári Mühely
}

\section{MTA Közgazdaság-tudományi Intézet, Budapest, 2017. augusztus 14-16.}

2017 nyarán 18. alkalommal került megrendezésre az MTA KRTK Közgazdaságtudományi Intézet Nyári Mühelye. Az eseményen a világ különböző részein tanuló vagy dolgozó magyar közgazdászkutatók ismertetik aktuális tanulmányaikat, amelyeket felkért hozzászóló véleménye egészít ki.

Sóvágó Sándor, az Amszterdami Szabadegyetem (Vrije Universiteit Amsterdam) hallgatója Obvious Mistakes in a Strategically Simple College-Admissions Environmen címen adta elő Ran Shorrerrel közös tanulmányát, amelyben azt vizsgálták, hogy a jelentkezők őszintén kinyilvánítják-e a preferenciáikat a stratégiailag egyszerü felvételi rendszerekben. A válaszuk negatív. A magyar felsőoktatási felvételi rendszert elemezve azt találták, hogy a jelentkezők nem elhanyagolható része dominált stratégiát játszik. Ezek a jelentkezők nyilvánvaló hibát (obvious mistakes) vétenek: úgy adják fel az államilag finanszírozott képzési forma lehetőségét, amelynek értéke szemeszterenként több százezer forint, hogy ebből a viselkedésből semmi hasznuk sem származik. Gyakran elöfordul, hogy a jelentkezőket felvették volna államilag finanszírozott képzésre, ha jelentkeztek volna. Ezek a nyilvánvaló hibák gyakrabban fordulnak elő a gyengébb tanulmányi eredményü, illetve jobb módú családi hátterủ hallgatók között. A költséges nyilvánvaló hibák forrásokat csoportosítanak át jómódú jelentkezőktől a hátrányos helyzetü diákokhoz, és növelik a felsőoktatásban részt vevő hallgatók számát. A cikk természetes kísérletként használja az államilag finanszírozott helyek 2012-es radikális csökkentését, amit a szerzők az érintett szakok szelektivitásának növeléseként értelmeztek. Azt találták, hogy egy adott szak szelektivitásának emelkedése növelte az oda jelentkezö hallgatók nyilvánvaló hibáinak számát.

Horn Dániel (MTA KRTK KTI) a bírálatában kifejtette, csodálkozik, hogy a szerzőpáros még nem küldte el folyóirathoz a tanulmányt, hiszen az már beadható állapotban van. De ha van lehetőség a javítására, akkor a Miért? kérdésre kellene nagyobb hangsúlyt fektetni. Miért van az, hogy a kevésbé jó képességű vagy a magasabb státusú tanulók követnek el több hibát? Vajon azért, mert a magasabb státusúaknak a kudarc (hogy nem veszik fel öket) költségesebb? Először is érdemes lenne e két háttérváltozó közvetlen hatása mellett az interakciós hatásukat is vizsgálni (Vajon a rosszabb

A kézirat első változata 2018. január 31-én érkezett szerkesztőségünkbe.

DOI: http://dx.doi.org/10.18414/KSZ.2018.3.325 
képességű és magas státusú tanulók követnek-e el több hibát?). Továbbá nemcsak a nyilvánvaló hibákra, de a költséges nyilvánvaló hibákra is vizsgálni kellene ezt az összefüggést. A hozzászóló néhány értelmezési kérdést is feltett, illetve robusztussági tesztet is javasolt, amelyeket Sóvágó Sándor helyben megválaszolt, illetve megköszönt.

Bayer Péter (University of Maastricht) Adaptive Learning in Weighted Network Games címen adta elö Jean-Jacques Herings, Ronald Peeters és Frank Thuijsman társszerzőkel készített tanulmányát. A szerzők súlyozott hálózatban párok közötti kapcsolatokat vizsgáltak adaptív tanulás mellett. Ez a fajta tanulás nagyon gyakran és a legkülönfélébb helyzetekben előfordulhat: vállalatok közötti kereskedelemtől a társas kapcsolatokig. A tanulmány megmutatja, hogy óvatos tanulás esetén a tanulási folyamat viszonylag gyenge feltevések mellett is a Nash-egyensúlyhoz konvergál, ha minden játékos rendszeresen felülvizsgálja a stratégiáját.

Bíró Péter (MTA KRTK KTI és BCE) kiemelte: a tanulmány gyakorlatilag egy lezárt cikk, ahol a kimondott tételek bizonyítása teljes. Nem volt világos számára, hogy a lépések sorrendje befolyásolja-e az egyensúlyt. Hasznos lett volna sztochasztikus szimulációval megnézni, milyen gyors a konvergencia. Ilyen jellegü játékokban nagyon hosszadalmas lehet a folyamat. A hozzászóló inkább a továbbfejlesztés lehetséges irányait vette számba: elsősorban is a játék menet közbeni változása lehet érdekes, például mennyiben befolyásolják a bizonyítást a partnerek között kialakuló együttműködések, koalíciók. Ez különösen akkor lehet érdekes, ha a konvergencia lassú.

Hörcher Dániel (Imperial College London), Daniel J. Graham és Richard J. Anderson tanulmányának címe: Travel passes in public transport. The interplay between crowding and road congestion externalities. A közösségi közlekedésben nagyon sok helyen lehet valamilyen bérletet venni, aminek következtében az egyes utazások marginális költsége nulla, ez pedig irracionálisan gyakori használatot generál. Amennyiben a közlekedési vállalat előre rögzített költségvetéssel dolgozik, ez a hálózat túlzsúfoltságán keresztül a társadalmi jólét csökkenéséhez vezethet. Elöfordulhat, hogy mind a vállalat pénzügyi helyzete, mind a társadalmi jólét rosszabb, mint ha minden utazásra külön kellene fizetni. A tanulmány bemutatja, hogy csak a súlyosan alulfinanszírozott közlekedési vállalatnál lehet magasabb a társadalmi jólét bérlethasználat mellett, különben a bérlethasználat jóléti veszteséget okoz. A szerzők egy parciális egyensúlyi modellben megmutatják, hogy a modell feltevései és a választott paraméterértékek mellett a közlekedési vállalatnak egyáltalán nem kellene bérletet árulnia, kivéve, ha a társadalmi optimum helyett más cél (például profit- vagy keresletmaximalizálás) vezérli. Az optimálisnál gyakoribb bérlethasználat oka kettős: a döntéshozók egyrészt figyelmen kívül hagyják a zsúfoltsági externáliát, másrészt a populista politika figyelmen kívül hagyja a jóléti szempontokat, mert a bérlet látszólag olcsóbbá teszi az utazást a választók számára.

Nagy Dávid (Centre de Recerca en Economia Internacional, Barcelona) hozzászólásában a kutatás relevanciáját dicsérte. Szerinte a jövőbeli munkának arra kell rávilágítania, hogy a tanulmány erös következtetése, hogy a bérlet árusítása széles tartományban csökkenti a társadalmi jólétet, megállja-e a helyét a függvényformák és paraméterértékek valós adatokon nyugvó megválasztása mellett is. 
Nagy Dávid immár kutatói szerepében a - Klaus Desmet, Robert Kopp, Michael Oppenheimer és Esteban Rossi-Hansberg szerzőtársakkal készített - saját tanulmányát adta elö Evaluating the Economic Cost of Coastal Flooding címmel, amely a klímaváltozás okozta tengerszint-emelkedés hatását számszerüsíti. Ez a folyamat a jövőben jelentősen befolyásolhatja a népesség földrajzi eloszlásának és a világgazdaságnak az alakulását. A szerzők ezeket a természeti hatásokat vizsgálják meg egy dinamikus gazdaságföldrajzi modell segítségével, amelyben a kereskedelem, a migráció és az innováció is endogén tényező. A modellt korszerü tengerszint-emelkedési elörejelzésekkel kombinálva a szerzők azt találják, hogy a tengerszint-emelkedés a világ reál-GDPjét nettó jelenértékben 0,22 százalékkal, a jólétet pedig 0,76 százalékkal veti vissza. A 2200-as évig a világ népessége 0,79 százalékának kell elköltöznie a tengerszint-emelkedés hatására (95 százalékos konfidenciaintervallum [0,20-1,51]). Bizonyos tengerparti területeken a veszteség nagyságrendekkel nagyobb: a tengerparti régiók 10 százaléka a reál-GDP-jének több mint 8 százalékát elveszíti.

Békés Gábor (CEU és MTA KRTK KTI) hozzászólásában rámutatott, hogy a klímaváltozás persze nagyon sok csatornán keresztül befolyásolja a gazdaság teljesítményét és a jólétet, de összességében a tengerszint-emelkedés hatása tulajdonképpen nem jelentős, bár ezt azok a csendes-óceáni szigetlakók másként gondolják, akiknek a szigetét teljesen elmossa majd a tengerár.

Simon Zorka (University of Mannheim) - Huszár Zsuzsával együtt írt - The Liquidity and Welfare Implications of the Securities Lending Market for European Treasuries címü tanulmánya azt tárgyalja, hogy napjaink alacsony kamatkörnyezetében az európai nyugdíj- és biztosítási alapok nehezen biztosítják a korábban ígért hozamokat. Ennek egyik oka az, hogy a hatályos prudenciális szabályozás miatt a befektetési portfólióik nagy arányban tartalmaznak alacsony kamatozású államkötvényeket. A probléma megoldásaként a szerzők az értékpapír-kölcsönzés gyakorlatát ajánlják, amelyen belül viszontbiztosított szerződéses keretek között, egynapos tranzakciók során az egyes állampapírok kölcsönadhatók más intézményi befektetőknek. Ez a gyakorlat kimutathatóan érinti a német államkötvények hozamát: minél több a kölcsönzési díjból származó várható bevétel az adott kötvényre, vagy minél nagyobb a specifikus kereslet, annál alacsonyabb az adott kötvény hozama (magasabb az ára). Ezen túlmenően az egyes kötvényeken kereshető kölcsönzési díj, valamint az azok iránti kereslet a kölcsönzési piacon likviditásra utaló magáninformációként szolgál mind az elsődleges, mind a másodlagos kötvénypiacokon, így segítve ezen eszközök árazását.

Berlinger Edina (BCE és MTA KRTK KTI) hozzászólásában ellenvéleményt fogalmazott meg. Szerinte a kölcsönzési díjak (körülbelül 15 bázispont $=0,15$ százalék) és az átlagosan kikölcsönzött kötvénymennyiség (körülbelül 6 százalék) ismeretében nehezen fogadható el a szerzők azon állítása, hogy alacsony kamatkörnyezetben a kötvényportfólió-kezelök számottevően növelhetik a portfólió hozamát egyes kötvények kikölcsönzésével. Különösen, ha figyelembe vesszük, hogy a kölcsönzési bevételek lehetőségét a piac beárazza, azaz a keresett kötvényeket némileg alacsonyabb hozammal lehet kibocsátani. A tanulmány fö eredménye éppen az, hogy a kölcsönzési díjaknak szignifikáns hatása van a későbbi hozamokra, vagyis a kölcsönzési díjak 
ismerete segít a hozamok előrejelzésében. A hozzászóló hiányolta annak részletezését, hogy ezt az információs előnyt milyen stratégiával lehet kihasználni, és nagyságrendileg mekkora többlethozam érhető el ezzel, reálisan figyelembe véve a szabályozási korlátokat (például hogy derivatív ügyletekkel az alapok többsége nem kereskedhet).

Hudomiet Péter (RAND Corporation) The Lifetime Risk of Dementia and the Distribution of Lifetime Out-of-pocket Medical Expenditures in the US címmel adta elö Michael Hurd és Susann Rohwedder társszerzőkkel készített tanulmányát. A demencia az idős társadalom jelentős részét érintő probléma, és egyike a legdrágább betegségeknek. Az Egyesült Államokban a költségek jelentős részét az állami Medicaid-programok állják az öregek otthonában való elhelyezések részleges támogatásával, másik részét pedig a családok fizetik. A szerzők először megbecsülik a demencia életciklus-kockázatát a Health and Retirement Study (HRS) adatain keresztül, amely az 50 év feletti amerikai lakosságot reprezentáló, longitudinális adatbázis. Majd a demencia családokra vonatkozó közvetlen kumulatív költségeit becsülik meg az egyének 65 éves korától halálukig. A cenzorált egyének hiányzó egészségügyi kiadásait egy nem parametrikus párosítási módszerrel füzik össze. Azt találják, hogy azon amerikaiaknak, akik 65 éves koruk után halnak meg, a 41,1 százaléka (standard hiba 3,3 százalék) legalább hat hónapig demens a halála előtt. A demencia életpálya-kockázata magasabb a nők, az alacsony iskolai végzettségüek és a feketék körében. Akik legalább hat hónapot élnek demensen, azoknak átlagosan 36000 dollárral (standard hiba 7000 dollár) kell többet fizetniük 65 éves koruktól halálukig (2014. évi dollárral és 0 százalékos diszkontrátával számolva). Ezek a költségek kizárólag a családok közvetlen kiadásait tartalmazzák. (A számítás során figyelembe veszik az egyének élethosszát, különböző demográfiai jellemzőit és a részletes egészségi állapotukat.) A 100000 dollárt meghaladó kiadások valószínüségét (ami nagyjából a kiadások 85. percentilise) pedig 13,7 százalékponttal (standard hiba 2,5 százalékpont) növeli meg a demencia.

Mihályi Péter (BCE) arra hívta fel a figyelmet, hogy az intézményes időskori ellátás - amely makroszinten minden országban egyre jelentősebb kiadásokkal jár - nem csak egyesült államokbeli probléma. Bármilyen meglepö - figyelembe véve a jelentős népességkülönbségeket -, Magyarországon relatíve közel 40 százalékkal több idős ember él úgynevezett öregek otthonában. Ráadásul ezek az otthonok méreteiket tekintve viszonylag kisebbek, ezért az intézmények száma nálunk 80 százalékkal több, mint az Egyesült Államokban. Nem vitatva a dolgozat érdemeit, a bíráló arra hívta fel a figyelmet, hogy a demencia csak az egyik gyakori ok, amiért a nagyon idős emberek (80 év felettiek) folyamatos - és ezért pénzben kifejezve mindenképpen nagyon költséges - felügyeletre-ellátásra szorulnak. Ilyen például a súlyos látáscsökkenés, az agyvérzés, a Parkinson-kór, illetve tágabb értelemben minden, ami ágyhoz kötöttséget eredményez (például baleset, szívelégtelenség, rák). Végül a bíráló megemlítette, hogy teljesen új helyzet állhat elö, ha bebizonyosodik, hogy az Alzheimerkór fertőzés útján (is) terjed(het).

Barkó Tamás (University of Mannheim) elöadásának címe: The Real Effects of Corporate Fraud. Ez a tanulmány az 1996 és 2016 közötti időszak egy átfogó, 1249 
bünügyet és 888 céget felölelő amerikai mintáján alapul. Az elemzés azt mutatja, hogy nagyobb valószínúséggel indítanak pert azon vállalatok ellen, amelyeket több részvénypiaci elemző követ, nagyobb méretüek, és/vagy rossz a részvénypiaci teljesítményük. A piacokon a per benyújtását negatív reakció övezi: a vállalati érték akár 2 milliárd dollárral vagy a piaci érték akár 62 százalékkal csökkenhet. Ez a hatás nagyobb mértékben jelentkezik, ha végül a céget elítélik, és kártérítésre is kötelezik. A részvényhozamok sem a per megkezdése után, sem az ítélet megszületésekor nem térnek vissza a korábbi értékre. A keresztmetszeti eredmények alapján azon cégek részvényeinek, amelyeknek több erőforrás áll rendelkezésükre a per folyamán, a tőkepiaci áresése kisebb mértékủ. Hasonló eredmény figyelhető meg azon vállalatoknál is, amelyeknek sokszínű az igazgatótanácsa. Ennek ellenére, a korábban magasan értékelt cégek, valamint azok, amelyek birodalomépítésre utaló jeleket mutatnak, jelentősen alacsonyabb hozamokkal számolhatnak.

Neszveda Gábor (University of Tilburg) hozzászólásában dicsérte a tanulmány ötletét és azt a munkát, amely az elemzéshez kellett. Hiányolta annak vizsgálatát, hogy ténylegesen mekkora a perköltség az érintett vállalatoknál, illetve a jóléti hatások elemzését. Meg kellene vizsgálni, hogy mennyi idő múlva halványul el a cég jó hírén esett folt. A hozzászóló hangsúlyozta, a hiányosságok mellett is nagyon érdekes, fontos és jól megírt tanulmányról szóló beszámolót lehetett hallani.

Horváth Bálint (University of Bristol) Harry Huizinga és Asli Demirgüc-Kunt társszerzőkkel készített, Foreign banks and International Transmission of Monetary Policy. Evidence from the Syndicated Loan Market címü tanulmánya azt vizsgálta meg, hogy a hitelezö külföldi bankok országainak monetáris politikája mennyire hat a hitelfelvevő cégek országára. A kérdés megválaszolásához azokat a szindikált hiteleket elemezték a szerzők, amelyekben a hitelnyújtó partnerek között külföldiek szerepelnek. Azt a köztudott tényt értelmezik újra, hogy a szükebb monetáris politika, azaz magasabb alapkamatszint mellett, a bankok csökkentik hitelkínálatukat külföldön. A tanulmány eredményei árnyalják ezt a képet: a külföldi hitel beáramlása azon országokba, amelyekben jelentős a külföldi bankok jelenléte, kevésbé kitett a külföldi monetáris politikai sokkoknak. Ennek részben az az oka, hogy a külföldi bankok fiókjai így védik hitelfelvevőikkel meglévő kapcsolataikat, másrészt maguk is kevésbé függnek az anyavállalat országában uralkodó finanszírozási körülményektől, mivel hozzáférnek a hitelfelvevő országában meglévő forrásokhoz.

Havran Dániel (BCE) hozzászólásában egyebek mellett további tesztek elvégzését - például a globális bankok likviditásallokációjának közvetlen vizsgálatát javasolta. Számára a kutatás fö kérdése az, hogy ha egy külföldi bank részt vesz egy szindikált hitel finanszírozásában, akkor mennyire játszik szerepet a folyósított hitel mennyiségében a külföldi bank országának monetáris/banki környezete? Felvetette, hogy érdemes lenne a tanulmányban említett két hipotetikus transzmissziós csatorna szerint felépíteni a dolgozat gondolati ívét. Az első csatorna: amelyik országban kisebb az informális aszimmetria, ott szívesebben hiteleznek a külföldiek; a másik: a globális bankok jobban képesek diverzifikálni a sokkok hatását azzal, hogy csökkentik aktivitásukat a kevésbé fontos célországokban. 
A diszkusszió érintette a fontosabb változókat és kisebb dilemmákat az empirikus modell fejlesztésével kapcsolatosan.

Péter Noémi (University of Groningen) Thomas Buserrel és Stefan Wolterrel közös, Gender, competitiveness and career choices along the whole ability distribution címü tanulmánya ahhoz a viszonylag friss irodalomhoz kapcsolódik, amely a versengési hajlandóságot, az ebben lévő nemi különbségeket és a diákok pályaválasztását vizsgálja. A korábbi tanulmányok elsősorban a legjobb képességü diákok körét elemezték. Ezzel szemben a dolgozat mintája több mint 1500 svájci iskolásból áll, akik a képességeloszlás különböző pontjain állnak. A diákok versengési hajlandóságát kísérleti úton mérték meg a tankötelezettség utolsó elötti évében, majd ezt összekapcsolták a másfél évvel később hozott továbbtanulási döntéseikkel. A főbb eredmények a következők: 1. A versengési hajlandóságban levő nemi különbség összefüggésben áll a képességekkel. Míg az eloszlás alján nincs különbség a fiúk és a lányok versengési hajlandósága között, addig a legkiválóbb diákok körében a fiúk versengési hajlandósága jelentősen magasabb. 2. A versengési hajlandóság a képességeloszlás minden szintjén elöre jelzi a tanulmányi döntéseket.

Adamecz-Völgyi Anna (Budapest Intézet) hozzászólásában annak fontosságát hangsúlyozta, hogy a dolgozat a diákok teljes iskolai eredmények szerinti eloszlása mentén vizsgálja a versenyszellem hatását az iskolaválasztási döntésre, míg a korábbi irodalom csak az eloszlás tetején tette ezt. A fiúk és a lányok esetében kapott eltérő eredmények újabb magyarázatot adhatnak a nemek pályaválasztási döntései és általában munkapiaci kimenetei közötti eltérésekre. A hozzászóló úgy vélte, hogy a kutatást segítheti, ha a szerzők megpróbálják pontosabban definiálni, hogy mit és hogyan mérnek. Például az iskolai osztályzatok átlaga nem kizárólag a készségeket méri, hanem a motivációt, a szociális beilleszkedést, de akár a továbbtanulási ambíciókat is, ezért érdemesebb lehet vagy „,iskolai eredmények szerinti” eloszlásról beszélni „készségek" helyett, vagy meg lehetne próbálkozni a kísérletben elért pontszámok alapján más mérőszámok konstruálásával is. Hasonlóképpen nehéz kérdés, hogy valójában mit ragad meg, ha egy foglalkozás matematikaintenzitását azzal mérjük, hogy az adott területen dolgozó emberek milyen eredményt érnek el egy matematikai teszten. Általános kognitív készségeket vagy a matematikai eszköztár intenzívebb használatát? Valószínűleg mindkettőt. Ha megoldani nem is lehet jelen kutatás keretében ezeket a kérdéseket, a hozzászóló véleménye szerint tárgyalni érdemes lenne őket.

Tétényi László (New York University) Regional Stabilization through Factor Mobility címü dolgozata a tőke és a munka mobilitásának, valamint a kormányzati redisztribúciónak a regionális stabilizációban betöltött együttes szerepét vizsgálja. A munkaerö és a tőke áramlása egy gazdasági térség régiói között az üzleti ciklusok során növelheti a jólétet, ha képes a régiók közötti újraelosztást növelni. A mechanizmus megértéséhez a szerző egy strukturális modellt számszerüsít az Egyesült Államok adatain. E modell a neoklasszikus elmélet egy olyan kiterjesztése, amelyben mind a tőke, mind a munkaerő áramlása engedélyezett a régiók között, és egy termelékenységi sokk utáni impulzus-válasz függvényeket számít. A modell képes a belső vándorlás prociklikusságának 
leírására, ahogy a lakosság jelentős számban hagyja el a gazdagodó tagállamokat is. Az emberek tagállamok közötti vándorlását a modell kimondottan jól becsüli, amikor a tagállamokon belüli régiók különbségeit is figyelembe veszi. A termelés és a bérek mozgását már kevésbé pontosan írja le, valószínűleg, mert a mostani specifikációban túl könnyü a tőkét áthelyezni. Az elözetes eredmények alapján a belső migráció költségének növekedése ahhoz hasonlóan hat az újraelosztásra, mintha a töke reallokációja lenne drágább: csökken a termelés, és nő a fogyasztás volatilitása.

Bisztray Márta (MTA KRTK KTI) hangsúlyozta, hogy a kutatás még folyamatban van, így még nem látszik, hogy melyik az a lehetséges irány, amely végül majd a fö hangsúlyt kapja. A kutatás legfontosabb újdonsága, hogy az irodalomban ezeknek a csatornáknak a szerepét eddig külön tekintették. A fő kérdés: a tőke vagy a munka mobilitása játszik-e nagyobb szerepet a termelékenységi sokkok tagállamok (vagy országok) közti terjedésében? Mi határozza meg az Európai Unió és az Egyesült Államok integrációja közti különbséget? Mi a tőke, a munka és a kormányzati újraelosztás együttes szerepe a stabilizációban? Ahogy Tétényi László maga is írja a tanulmányban, a modell várhatóan még több elemmel fog gazdagodni, mint például a tőkepiac részletgazdagabb kidolgozása, illetve a kormányzati redisztribúció beemelése. Bisztray Márta a bírálat mellett hangsúlyozta, a tanulmány jelenlegi változata és a további tervek alapján egy figyelemre méltó cikkre számíthatunk.

Kiss Tamás (University of Göteborg) Vanishing Predictability and Non-Stationary Regressors címmel a részvényhozamok előrejelzésének ökonometriai problémáiról beszélt, különös tekintettel a nagyon perzisztens előrejelző változókra. A szerző az egyváltozós lineáris modellt vizsgálta, és bemutatta, hogy ha a magas perzisztenciát egy nem starcioner zaj okozza, akkor a minta elemszámának növekedésével a klaszszikus legkisebb négyzetes becslés torzítása nő, így az eredmény kevésbé megbízhatóvá válik. A probléma enyhítésére a szerző egy új becslési eljárást javasol („almintás fix hatások"). Az eljárás lényege, hogy az együtthatók becslése almintánként történik, ami csökkenti a nem stacioner zaj hatását, így a becslés torzítása csökken. Szimulációk használatával Kiss Tamás megmutatja, hogy a nagymintás elméleti eredmények kisebb elemszám esetén is érvényesek, és a javasolt becslési eljárás robusztus az adatgeneráló folyamatra vonatkozó feltevésekre.

Lieli Róbert (CEU) alternatív magyarázatokat fogalmazott meg a vizsgált jelenségre. Kiemelte a strukturális törések fontosságát. Hiányolta az endogenitás szerepének pontosabb elemzését. Hangsúlyozta, hogy differenciált modellben a torzítás nem nő a mintaelemszám növekedésével, de kiemelte, hogy egy érdekes probléma szellemes megoldását láthatjuk a tanulmányban.

Simonovits Gábor (New York University) The institutional sources of policy bias címmel tartott elöadásának alapkérdése: milyen jól képviseli a közpolitika a lakosság preferenciáit. Ezt a kérdést az Egyesült Âllamok tagállamainak minimálbéremelési döntései alapján vizsgálja. Az elemzés fontos jellemzője, hogy a lakosság preferenciáit egy nagyon részletes területi bontású minta alapján elemzi. Legfontosabb tanulsága, hogy a minimálbér megállapításánál általában figyelmen kívül 
hagyják a lakosság preferenciáinak jelentős heterogenitását, ami a szegényeket érinti hátrányosan. Az eredmények azt mutatják, hogy ha a minimumbért nem állami, hanem alacsonyabb - például városi - szinten határoznák meg, az a területek jelentős részén lényegesen magasabb lenne.

Simonovits Gábor tanulmányát Lindner Attila (University College London) diszkutálta. Megállapította, hogy a tanulmány a politikatudomány egy fontos kérdésére - az adott közpolitika és a választók preferenciája között mennyire szoros a kapcsolat - ad újszerü, kreatív választ, és feltehetően nagy hatással lesz az irodalomra. A Simonovits Gábor által kifejlesztett módszert sokan fogják alkalmazni. E módszer itt most annak becslésére szolgál, hogy vajon az Egyesült Államokban a minimálbér szintje tükrözi-e a választói akaratot. A tanulmány egyik fö következtetése, hogy a minimálbér jobban tükrözné a választói akaratot, ha állami szintről decentralizálnák városi szintre. Ezt a konklúziót a hozzászóló túl erősnek találta, mivel a választók minimálbérrel kapcsolatos preferenciája az állami, nem pedig a városi minimálbérre vonatkozik. Az előadónak az az implicit feltételezése, hogy a választók hasonlóan gondolkodnak a városi, az állami és a szövetségi minimálbér szintjéről, további bizonyítást igényel.

Hozzászólása után Lindner Attila mindjárt elö is adta Doruk Cengiz, Arindrajit Dube és Ben Zipperer társszerzőkkel írt, The effect of minimum wages on the total number of jobs. Evidence from the United States using a bunching estimator című tanulmányát. Ebben egy új empirikus módszert alkalmaztak, amely a béreloszlás segítségével becsüli meg annak foglalkoztatási hatásait. Ebből kiderült, hogy a minimálbér felett megfigyelhetö torlódásból (bunching) és az új minimálbér alatti dolgozók számának csökkenéséből megbecsülhető a minimálbér teljes foglalkoztatottságra gyakorolt hatása. A minimálbér béreloszlásra gyakorolt hatásának a - Current Population Survey (CPS) adataival végzett - becsléséhez a szerzők kihasználták, hogy 1979 és 2015 között az Egyesült Államokban megváltoztak az állami minimálbérek. Megmutatták, hogy az új minimumbér alatt fizetendő hiányzó munkahelyek száma megegyezik a minimálbér felett keletkező új munkahelyek számával, ami arra utal, hogy a foglalkoztatottsági hatás elenyésző volt. Az elsődleges specifikációból származó konfidenciaintervallumok kizárják, hogy a foglalkoztatottsági hatás jelentős, miközben a bérek szignifikánsan emelkedtek. A tanulmány azt is megmutatta, hogy a minimálbérnek nincs foglalkoztatottsági hatása azokban a csoportokban sem, amelyek szakpolitikai szempontból relevánsak: alacsony végzettségü férfiak, fekete vagy spanyol munkások.

Vincze János (BCE és MTA KRTK KTI) hozzászólásában két problémát vetett fel: az alkalmazott módszer negligálja a „minimálbér-meghatározási” mechanizmust, és nem veszi figyelembe az amerikai munkapiac integráltságát, ami azt jelenti, hogy egy bizonyos tagállam minimálbér-változtatásának befolyással kell lennie más tagállamok munkapiacára is. Érdekesnek találta, hogy a tanulmány kimutatja: más tanulmányok negatív elaszticitásai a minimálbértől távoli megfigyeléseknek tulajdoníthatók, és nem tükröznek okozati összefüggést.

Vadász Tamás (University of Warwick) - Kebin Ma társszerzővel készített - Bank Signalling, Risk of Runs, and the Informational Impacts of Financial Regulations 
címü tanulmányában a bankok és a szabályozók közötti interakciókat vizsgálja. A bankok a költséges akciókkal tudják demonstrálni, hogy jól müködnek, elég likvidek, és így képesek ellenállni az esetleges válsághelyzeteknek. Ezek a döntések persze a bank valódi kockázatát is befolyásolják, de egy szeparáló egyensúly kétféle hatékonytalansággal is jár: a jó bankok túl költséges beruházásokat választanak, míg a rosszaknak ezek a megkívánt költségek érdemben rontják a stabilitását. Az elméleti modell következtetéseit alátámasztja az Egyesült Államok tőke- és likviditási szabályozásának elemzése is. A szabályozó elég magas tőke- és likviditási mutatók előírásával képes túl drágává tenni a szeparáló egyensúlyt, és így minden bank inkább csak az elöírt tőkét és likviditást tartja. A mechanizmus a következő: a rossz bankok csak névleg tudnak felmutatni likviditást és tőkét, ezek krízishelyzetben nem sokat érnek. A probléma viszont, hogy a rossz bankok megpróbálják emulálni a jó bankokat, hogy ezzel megelőzzék a bankrohamokat. Mivel egy ilyen elvegyítő egyensúly rossz a jó bankoknak, ők egyre extrémebb tőke- és likviditási tartalékokkal próbálják megkülönböztetni magukat a rossz bankoktól. A tanulmány rámutat, hogy ez az egyensúly pazarló, és megfelelő pénzügyi szabályozással orvosolható. A tőkeminimum- és likviditási előírásoknak meglepő következményei lehetnek: egyes (jó) bankok csökkentik a tartalékaikat. Meglepő módon ez társadalmilag hasznos lehet.

A felkért hozzászóló, Zawadowski Ádám (CEU) hangsúlyozta a tanulmány fő kérdésének jelentőségét: a bankok hogyan használhatják a tőke és likviditási mutatóikat annak jelzésére, hogy képesek kivédeni egy esetleges bankválságot. A bemutatott mechanizmus számára újnak és érdekesnek tủnik, és néhány furcsaságot jól megmagyaráz a modell. Kimondottan elegáns, ahogy a globális játékot összeköti a jelzésekkel. Reméli, hogy sikerül a közeljövőben egyértelmüen kimutatni az adatokban, hogy a minimum-elöírások tényleg csökkenthetik a bankok tartalékait.

Pogonyi G. Csaba (Imperial College London) Daniel J. Graham szerzőtárssal készített, Firms, agglomeration and congestion. Comparing the impacts of different measures of accessibility on productivity címủ tanulmányának legfontosabb célja, hogy megvizsgálja a földrajzi elérhetőség alternatív méréseinek hatását az agglomerációs rugalmasság becslésére. A szerzők új távolságmátrixot készítettek az angol telephelyek közötti - a gépjármüvek autópályákon mért sebességét is figyelembe vevő - forgalomszámlálási adatokból. Ezek segítségével a cégek közötti időben mért távolságot csúcsforgalmi és azon kívüli időszakokra bontották. Majd a távolságmátrixot felhasználva kiszámolták a telephelyek térségében foglalkoztatottak földrajzi sürűségét (mean effective density), és a sürüség alapján iparágak szerint összehasonlították a vállalatok teljestényezö-termelékenységének növekedését. Az ezzel a mértékkel készült becslések jelentősen eltérnek a korábbiaktól, esetenként akár háromszorosai is lehettek. Az előzetes eredmények azt sugallják, hogy a magas hozzáadott értékủ szolgáltató iparágakban (például pénzügyi és informatikai szektorban) fontosabb a telephelyek jó elérhetősége, mint a feldolgozóipari vagy logisztikai iparágaknál. Mindez arra enged következtetni, hogy elsősorban a szolgáltató vállalatok képesek alacsony közlekedési költségekkel járó telephely kiválasztásával növelni termelékenységüket. 
Lengyel Balázs (MTA KRTK KTI) hozzászólásában nagyon érdekesnek nevezte a távolság mérését, de hiányolt számos részletet a tanulmányból. Jó néhány potenciális problémát is felvetett. Például: a nagyvárosok centrumait kihagyja a tanulmány, de ennek jelentős hatása lehet például a vállalatok ágazati szerkezetére, amit mindenképp vizsgálni kellene. Hiányolta a térbeli elemzés részleteit, az adatok térbeli szerkezetének bemutatását. Felhívta a figyelmet arra, hogy a panelmodell nagyon fontos változói - a távolság, a zsúfoltság - vagy állandók, vagy nagyon perzisztensek, így a becslés valójában kevés érdemi változásból történik. Ez lehet a magyarázata annak, hogy sok együttható becslése nem szignifikáns. Érdemes lenne összehasonlítani az utazási időt a vállalat döntéshozói közötti kapcsolatok intenzitásával. Összességében ez egy nagyon érdekes munka, de még van hátra néhány feladat.

Füleky Péternek (University of Hawaii) a Luigi Ventura és Qianxue Zhao szerzőtársakkal Common Correlated Effects and International Risk Sharing címen írt tanulmányát egy folyóirat közlésre már el is fogadta. A fogyasztási kockázat helyes megítélése és nemzetközi elosztása komoly gazdaságpolitikai következményekkel jár. Ennek ellenére az eddigi tanulmányok ezen a téren olyan irreális feltételezéseket használtak, mint hogy a világ minden gazdaságában azonos preferenciák uralkodnak, és a globális hatású sokkok egyformán éreztetik hatásukat. A tanulmány szerzői feloldják ezeket a homogén megkötéseket, és összehasonlítják az általuk javasolt módszert az eddig használtakkal egy 45 évet átfogó és 120 ország adatait tartalmazó paneladatbázis alapján. Az eredmények igazolják, hogy a fogyasztás csak részben diverzifikált nemzetközileg, és a kockázat megosztása egyenesen arányos a gazdasági fejlettséggel, viszont az elmúlt négy évtizedben lezajlott pénzügyi globalizáció hatása nem nyilvánul meg a kockázatmegosztás növekedésében.

Csóka Péter (BCE és MTA KRTK KTI) hozzászólásában kiemelte, hogy jól megírt és már kicsiszolt tanulmányt értékelhet. A fö kérdés az, hogy mennyire teljesek a nemzetközi fogyasztás simítását lehetővé tevő piacok, vagy mennyire lehet minden lehetséges jövőbeli világállapotra szerződést kötni. Ha teljesek a piacok, akkor (az eddigi homogén feltevések mellett) az intertemporális helyettesítési határráták kiegyenlítődnek, ami tesztelhető összefüggéshez vezet. A szerzők ezt az összefüggést írják fel és tesztelik nem homogén feltevések mellett, így meg tudják vizsgálni, hogy az országok egyedi jövedelemsokkjai hogyan hatnak a nem diverzifikálható fogyasztásra. A hozzászóló szerint a piacok teljessége nemzetközi szinten azért nem várható, mert az aszimmetrikus információk miatt a fogyasztók befektetéseikkel nemzetközi szinten nem diverzifikálnak eléggé. Ezenkívül felmerült további lehetséges panelmódszerek és kísérleti közgazdaságtan alkalmazása is.

A Nyári Mühely honlapján (http://econ.core.hu/esemeny/nym_hun.html) megtalálható a mühely programja és az elöadott tanulmányok többségének szövege. 